УДК 373.1

DOI:

Галина Білавич, доктор педагогічних наук, професор кафедри педагогіки початкової освіти ДВНЗ “Прикарпатський національний університет імені Василя Стефаника”

\title{
РОЗВИТОК ДОСЛІДНИЦЬКИХ УМІНЬ ШКОЛЯРІВ У ПРОЦЕСІ ВИВЧЕННЯ ПРЕДМЕТІВ ПРИРОДНИЧО-МАТЕМАТИЧНОГО ЦИКЛУ В АВТОРСЬКИХ ШКОЛАХ УКРАЇНИ (70-80-ті рp. ХХ ст.)
}

Стаття присвячена проблемі розвитку дослідницьких умінь школярів у прочесі вивчення предметів природничо-математичного иџклу в авторських школах України (70-80-ті рр. ХХ ст.). Саме за цього періоду в українській історико-педагогічній думиі, в освітній практичі нагромаджено значний пласт науковотеоретичних розробок, успішно реалізовано низку проєктів, які варто із позииій сьогодення глибоко вивчити й проаналізувати, творчо застосовувати з урахуванням конкретної освітньо-педагогічної ситуації.

Ключові слова: природничо-математичні дисиипліни; досліднищькі вміння; авторська школа; педагогноватор; учні.

Лim. 7.

Halyna Bilavych, Doctor of Sciences (Pedagogy), Professor of the Pedagogy of Primary Education Department, State Pedagogical University "Vasyl Stefanyk Precarpathian National University"

\section{DEVELOPMENT OF RESEARCH SKILLS OF SCHOOLCHILDREN IN THE PROCESS OF STUDYING SUBJECTS OF NATURAL AND MATHEMATICAL CYCLE IN AUTHOR'S SCHOOLS OF UKRAINE (1970-1980s)}

The article is devoted to the problem of development of research skills of schoolchildren in the process of studying the subjects of natural-mathematical cycle in the author's schools of Ukraine (70-80s of the XX century). It was during this period that many scientific and theoretical developments were accumulated in Ukrainian historical and pedagogical thought and a number of projects were successfully implemented, which should be deeply studied, analyzed, and creatively applied today. An innovative pedagogical movement in Ukraine in the 70-80s of the XX century was accompanied by constant reforms and the search for optimal models of teaching and education. There were at least 40 educational author's institutions, almost half of which operated in the Kirovograd region. A prominent place in the activities of author's schools was occupied by the research during the classes of the naturalmathematical cycle.

The article analyzes the experience of V. Sukhomlynskiy and M. Kodak (Pavlysh Secondary School, Kirovohrad Region), K. Holoborodko (Stanislav Secondary School, Kherson Region), A. Solohub (Kryviy Rih (formerly Saksagan Secondary School) Natural Science Lyceum), V. Repkin (Kharkiv Secondary School №17), N. Kalinichenko (Komyshuvate Secondary School, Kirovohrad Region), I. Tkachenko (Bohdaniv Secondary School, Kirovohrad Region), F. Oksanych (Novopraha Secondary School, Kirovohrad Region), M. Kofman (Novoukrayinsk Secondary School № 6, Kirovohrad region), which turned the educational institutions they headed into real scientific and pedagogical laboratories of labor training, education and vocational guidance, laid the theoretical foundations of productive learning, developmental learning. Such integration of learning and productive work took place not only in classrooms, but also in the production environment, in interaction with the production complex, educational and research area. All this served the development of research skills of schoolchildren, contributed to research activities, mental development of students, provided practical preparation of youth for life, and formed a harmoniously developed personality. In the 70's of the XX century A. Sologub, a chemistry teacher, later the head of the Kryviy Rih (formerly Saksagan) Lyceum of Natural Sciences substantiated and implemented the concept of creative natural education. Through active research activities in class and during extracurricular activities, students acquired deeper, compared to the curriculum, knowledge in the field of natural sciences.

Keywords: natural and mathematical discipline; research skills; the author's school; a teacher-innovator; schoolchildren.

П остановка проблеми. За умов упровадження Концепції Нової української школи, становлення і розвитку високотехнологічного інформаційного суспільства в Україні виникає необхідність підвищення якості та пріоритетності природничо- математичної освіти, включення предметів природничо-математичного циклу до навчальних планів усіх рівнів освіти, поліпшення математичної підготовки юнацтва, що зумовлено, окрім іншого, і тим, що з 2021 р. в Україні запроваджується дворівнева (легший та складніший рівні, залежно 
РОЗВИТОК ДОСЛДНИЦЬКИХ УМІНЬ ШКОЛЯРІВ У ПРОЦЕСІ ВИВЧЕННЯ ПРЕДМЕТІВ ПРИРОДНИЧО-МАТЕМАТИЧНОГО ЦИКЛУ В АВТОРСЬКИХ ШКОЛАХ УКРАЇНИ (70-80-ті рр. ХХ ст.)

від потреб вступника) обов'язкова державна підсумкова атестація з математики у формі ЗНО. Як зазначають фахівці [2, 72], ситуація ускладнюється і тим, що інтерес у школярів до предметів математично-природничого циклу знижується, що відображається на їхніх низьких результатах $3 \mathrm{HO}$ математики, це засвідчують i показники Міжнародного звіту за результатами міжнародного дослідження якості освіти PISA-2018 (PISA Programme for International Student Assessment), участь у якому Україна вперше взяла [7].

Реформування вітчизняної системи освіти та перехід до нової компетентнісної освітньої моделі передбачає переоцінку чинних освітніх теорій та концепцій і розроблення нових. Природничоматематична освіта учнів має відбуватися 3 урахуванням нових запитів суспільства щодо підготовки фахівців, що сприяє пошуку відповідних форм, методів та засобів навчання. Важливим у цьому процесі $є$ і виокремлені ідеї позитивного ретроспективного досвіду природничо-математичної освіти в Україні в другій половині XX ст. та можливості їх творчого впровадження в сучасних закладах освіти.

Аналіз останніх досліджень і публікацій. Окремі проблеми, пов'язані 3 історією педагогічного новаторства в Україні в другій половині XX ст., були предметом осмислення вчених (Л. Березівська, Н. Гупан, Н. Дічек, I. Зайченко, Н. Калініченко, М. Проц, Н. Побірченко, О. Сухомлинська, М. Чепіль, Ю. Юрчонок та ін.). Нагромаджено напрацювання щодо досліджень теорії і практики інноваційних освітніх технологій (Л. Даниленко, І. Дичківська, Н. Ничкало, В. Сластьонін, О. Попова та ін.). Розроблено теоретико-методологічні засади розвитку дослідницьких умінь учнів на уроках природничоматематичних дисциплін у закладах загальної середньої освіти (кінець 50 - початок 90-х рр. ХХ ст.) (Н. Галицька, І. Карташова, Л. Марецька та ін.). Проте заявлена в назві статті проблема недостатньо повно висвітлена в науковій літературі.

Мета статті - проаналізувати розвиток дослідницьких умінь школярів у процесі вивчення предметів природничо-математичного циклу в авторських школах України (70-80-ті рр. ХХ ст.).

Виклад основного матеріалу. Науковці (М. Проц [5], Ю. Юрчонок [6] та ін.) слушно зазначають, що поняття “авторська школа” - складне, багатопланове й учені інтерпретують його порізному, нерідко трактують довільно в ракурсі своїх дослідницьких проєктів.

Ми насамперед характеризуємо авторську школу як педагогічне явище, як інноваційну педагогічну систему. Ï̈̈ функціонування передбачає певну стратегію відносин об'єктів навчально-виховного процесу, як-от: природо- і культуровідповідність, гуманізація, цілісність, індивідуально-особистісний підхід, віра в дитину, єдність педагогічних дій і способу життя учня тощо. Авторська школа - це особливий освітній простір, який визначає іiі внутрішню життєдіяльність у вигляді особистісних якостей, цінностей, орієнтацій організатора та керованих ним педагогічного й учнівського колективів, особливих традицій закладу $[5,12]$.

З урахуванням реалій доби, що досліджується, авторську школу розуміємо як новаторський за змістом та методами, засобами, формами організації навчально-виховного процесу загальноосвітній заклад, очільником якого $\epsilon$ креативний директор, що здатний згуртувати й мобілізувати задля втілення у життя авторської педагогічної системи/концепції педколектив та учнівство, створивши для цього необхідний соціокультурний освітній простір. Діяльність авторської школи за доби радянського тоталітаризму детермінувалася панівною офіційною ідеологією, авторитарною педагогікою, державною освітньою системою тощо. Ці чинники не завжди прихильно реагували на освітні інновації та експериментування в царині навчання і виховання дітей й юнацтва. Утім, саме за 7080-ті pp. ХХ ст. в українській історико-педагогічній думці, в освітній практиці нагромаджено значний пласт науково-теоретичних розробок, успішно реалізовано низку проєктів, які варто із позицій сьогодення глибоко вивчити та проаналізувати, творчо застосовувати з урахуванням конкретної освітньо-педагогічної ситуації.

Новаторсько-педагогічний рух в Україні в 7080-ті pp. ХХ ст. супроводжувався постійними реформуваннями та пошуком оптимальних моделей навчання і виховання. Помітне місце в цьому процесі посіло дослідництво на уроках природничо-математичного циклу в загальноосвітніх школах. За даними дослідниці М. Проц, за цього періоду виникли та успішно функціонували щонайменше 40 навчально-виховних авторських закладів, майже половина 3 яких діяли на Кіровоградщині $[5,24]$. Таке самобутнє освітньопедагогічне явище у вимірі тодішнього радянського, пострадянського та європейського освітнього простору було зумовлено новаторською діяльністю Великого Гуманіста XX ст. В. Сухомлинського (1918-1970рр.), який власним прикладом (як очільник Павлиської середньої школи) започаткував створення когорти кіровоградського грона педагогів-новаторів [3]. 
РОЗВИТОК ДОСЛІДНИЦЬКИХ УМІНЬ ШКОЛЯРІВ У ПРОЦЕСІ ВИВЧЕННЯ ПРЕДМЕТІВ ПРИРОДНИЧО-МАТЕМАТИЧНОГО ЦИКЛУ В АВТОРСЬКИХ ШКОЛАХ УКРАЇНИ (70-80-ті рр. ХХ ст.)

Розглянемо окремі здобутки авторських шкіл крізь призму порушеної нами проблеми.

Одну з новаторських ідей В. Сухомлинського - школа просто неба - успішно розвивав його прямий “спадкоємець” М. Кодак, який по смерті В. Сухомлинського став директором у Павлиші. Характерною особливістю діяльності більшості авторських шкіл стала інтеграція освітнього процесу, актуалізація пошуково-дослідницьких методів у навчанні. До прикладу, М. Кодак, учитель-словесник, розробив оригінальну методику розвитку дитячого мислення, пам'яті, фантазії.

Так, для розвитку пізнавальних можливостей учнів на уроках математики, природознавства та інших предметів використовувалися збірники диктантів, переказів, самостійних завдань тощо, що спонукало школярів створювати казки, моделювати довкілля (шкільне подвір'я, поле, ферму та ін.) на основі знань, здобутих у процесі вивчення природознавства, біології, математики, географії, фізики тощо. Цьому сприяло проведення уроків у “зеленому класі” (за В. Сухомлинським, “уроки мислення в природі”), у формі екскурсій у природу, а також до виробничих підприємств, громадських установ тощо [3].

Дослідництво як провідний навчальний метод застосовували і в Станіславській школі (Херсонщина), що засвідчують результати аналізу творчих надбань іï директора К. Голобородька. Оригінальність авторської педагогічної концепції полягала в інтеграції двох основних напрямів політехнічно-трудового та гуманітарноестетичного, що знайшло вияв у поєднанні навчання 3 продуктивною й суспільнокорисною трудовою діяльністю дітей.

Концепція креативної природничої освіти була започаткована на початку 1970-х рр. А. Сологубом, учителем хімії, згодом очільником Криворізького (раніше-Саксаганського) природничо-наукового ліцею. Через активну науково-пошукову діяльність на уроках та в позаурочній діяльності учні набували глибші, порівняно $з$ навчальною програмою, знання в ділянці природничих дисциплін $[1 ; 4]$. Модель становлення і розвитку творчої особистості учня можна умовно представити у формі піраміди: вершину становить “дослідник-філософ’ (постійний пошук істини, науковий світогляд вільної людини); “дослідникгромадянин” (висока національна свідомість); “дослідник-винахідник” (практичне мислення); “дослідник-експериментатор” (науково-практичне мислення); “дослідник-теоретик” (науковотеоретичне мислення - генерування ідей). Цьому слугували різноманітні форми здобуття природничих знань, в основі яких - дослідництво: творчі уроки; лекції, вільні та керовані діалоги (аристотелівські та сократівські бесіди); евристичні бесіди; наукові й навчальні семінари, дискусії, диспути; факультативи, конференції; захист науково-дослідницьких робіт; наукові звіти; конкурси, виставки, клуби за інтересами, екскурсіі, вечори запитань і відповідей та ін. [5, 35].

Отже, уже у 70-80-х pp. XX ст. педагогноватор А. Сологуб замість навчально-урочної діяльності запроваджував навчально-дослідницьку діяльність 3 оригінальною типологією уроків. Звісно, що найповніше реалізувати свою авторську концепцію вчений зміг тільки за доби новітньої незалежності України, започаткувавши один 3 перших ліцеїв у нашій державі - Криворізький (Саксаганський) природничо-науковий ліцей, який очолював 31990 до 2007 р. [1, 3].

Авторська концепція харківського педагога В. Рєпкіна, що грунтувалася на психологопедагогічній системі розвивального навчання, була успішно втілена впродовж 1963-1983 pp. у діяльності лабораторії навчальної діяльності в школі № 17. У теорії навчальної діяльності педагог активно працював над проблемами особистісної мотивації дитини та навчального цілепокладання тощо [5, 67].

На таких особистісно орієнтованих засадах навчання, інтеграції освітнього процесу базувалася й діяльність іншої харківської авторської школи “Очаг”, яка бере свій початок 1979 р., коли фізик В. Ямпольский, математик С. Курганов, літератор В. Литовський, історик I. Соломадін почали проводити уроки-діалоги, на яких учні не лише здобували знання, а й обстоювали власне індивідуальне бачення навчальних і життєвих проблем. Упродовж майже десятьох років (1979-1987) творчі педагоги за керівництва вченого-філолога В. Біблера розробили навчальну концепцію діалогу культур та методи проведення уроків-діалогів 3 математики, природознавства, літератури, історії, яка найповніше була реалізована у 90-х рр. ХХ ст. Їх головна суть полягала у тому, що базові шкільні знання і поняття засвоювались учнями за методикою ведення діалогу, в онові якої пошуковоевристична діяльність. За результатами вивчення дитячих діалогів про “число та слово”, що відбувалися на уроках учителів-“діалогістів”, були укладені авторські навчальні посібники “Загадки числа”, “Загадки слова” (І. Берлянд), “Загадки природи” (А. Юшков) та ін. [5, 80].

Унікальна освітньо-педагогічна модель екологічної школи народознавчого спрямування склалася в Комишуватській середній школі, що 
на Кіровоградщині, яку впродовж 1972-1996 pp. очолювала Н. Калініченко. Ї̈̈ діяльність грунтувалася на засадах пізнання і збереження рідного краю. Члени гуртків "Рідна природа" та юних агрохіміків активно займалися наукопошуковою та дослідницькою діяльністю, брали участь уприродоохоронних заходах. Інноваційність авторської моделі Н. Калініченко полягала насамперед у тому, що учні за керівництва педагогів залучалися до розроблення методики проведення уроків “спілкування 3 природою”, "мислення та моральності” тощо. Послуговуючись сучасною термінологією, вони створювали змістовні наукові проєкти (“Лікарські рослини рідного краю”, “Сторінками книги про природу”, “Символіка рослин рідного краю”, “Символіка рослин у давніх обрядах і піснях” та ін.). Здобуті теоретичні знання школярі закріплювали працею на дослідній ділянці, де набували необхідних для подальшого життя трудових умінь і навичок. Ця “жива книга природи” - так комишуватівські школярі називали своє дослідницьке поле поділялася на окремі відділи: польовий, овочевий, сівозмінний, плодоягідних культур, селекційногенетичний, лікарських рослин. У збудованому поряд 3 полем т. зв. зеленому класі проводили уроки біології та позакласних занять відповідного спрямування [3, 218-219; 5].

Подібні підходи властиві й авторським педагогічним системам I. Ткаченка (Богданівська середня школа Знам'янського району Кіровоградської області), Ф. Оксанича (Новопразька середня школа Олександрійського району Кіровоградської області), М. Кофмана (Новоукраїнська середня школа № 6, що на Кіровоградщині), які перетворили навчальні заклади, які очолювали, на справжні науково-педагогічні лабораторії трудового навчання, виховання і професійної орієнтації, заклавши теоретичні засади продуктивного навчання, організації навчальної діяльності на уроках з природничих і спеціальних дисциплін. Така інтеграція навчання та продуктивної праці мала відбуватися не лише на уроках у класах, а й у виробничому середовищі, у взаємодії з виробничим комплексом, навчальнодослідницькою ділянкою. Усе це слугувало розвитку дослідницьких умінь школярів, сприяло науково-пошуковій діяльності, розумовому розвитку учнів, забезпечувало практичну підготовку юнацтва до життя, формувало гармонійно розвинену особистість.

Висновки та перспективи подальших досліджень. Отже, досвід діяльності авторських шкіл в Україні в 70-80-х рр. ХХ ст. щодо розвитку дослідницьких умінь учнів у процесі вивчення предметів природничо-математичного циклу є актуальним і значущим для розвитку сучасної освіти та виховання. Творче використання теорії і практики формування цих та інших авторських моделей сприятиме ефективному реформуванню сучасної системи освіти в Україні та вдосконаленню педагогічних технологій викладання природничо-математичних дисциплін, подальшому розвитку розвивального навчання, яке стало одним 3 провідних складників функціонування авторських шкіл В. Сухомлинського, I. Ткаченка, Н. Калініченко, Ф. Оксанича, Ф. Кофмана, Г. Бойка, К. Голобородька, М. Кодака, А. Сологуба, В. Біблера та ін. Подальших наукових пошуків заслуговує наукова проблема формування дослідницьких умінь учнів у типових загальноосвітніх закладах другої половини XX ст.

\section{ЛІТЕРАТУРА}

1. Гончаренко С. Авторська школа креативності. Рідна школа. 2007. № 9. С. 3-4.

2. Довгий О. Формування інтересу до математики в учнів у закладах позашкільної освіти. Молодь і ринок. 2020. № 5(184). С. 72-77.

3. Калініченко Н. А., Перебийніс Г. М. Сучасники В. О. Сухомлинського. Кіровоград : Народне слово, 1998. 260 с.

4. Марецька Л. П., Галицька Н. Є. Дослідництво як один із засобів розвитку дослідницьких умінь учнів на уроках природничих дисциплін (кінець 50 х - початок 70-х рр. ХХ ст.). Педагогічний альманах. 2020. № 44. С. 276-283. https://doi.org/ 10.37915/pa.vi44.49.

5. Проц М. Педагоги-новатори України : [навч. посіб.]. Львів : Бадікова Н. О., 2015. 148 с.

6. Юрчонок Ю. В. “Авторська школа”: до визначення сутності поняття. Гуманізація навчально-виховного процесу : зб. наук. праць. Слов'янськ : Вид. центр СДПУ, 2009. Вип. XLVI. C. 293-296.

7. OECD (2019) PISA 2018 Results (Volume I): What Students Know and Can Do, PISA, OECD Publishing, Paris, 352 p. https://doi.org/10.1787/ 5f07c754-en.

\section{REFRERENCES}

1. Honcharenko, S. (2007). Avtorska shkola kreatyvnosti [Author's school of creativity]. Native school. No. 9. pp. 3-4. [in Ukrainian].

2. Dovhiy, O. (2020). Formuvannia interesu do matematyky v uchniv u zakladakh pozashkilnoi osvity [Formation of students' interest in mathematics at extracurricular educational institutions]. Youth \& market. No. 5 (184). pp. 72-77. [in Ukrainian].

3. Kalinichenko, N. A. \& Perebyinis, H. M. (1998). 


\section{РОЗВИТОК ТЕОРЕТИЧНИХЗАСАДВИХОВАННЯ ДІТЕЙ У ЗАКЛАДАХДОШКІЛЬНОЇ ОСВІТИПОЛЬЩІ}

Suchasnyky V. O. Sukhomlynskoho [Contemporaries of V. Sukhomlinsky]. Kirovohrad, 260 p. [in Ukrainian].

4. Maretska, L. P. \& Halytska, N. Ye. (2020). Doslidnytstvo yak odyn iz zasobiv rozvytku doslidnytskykh umin uchniv na urokakh pryrodnychykh dystsyplin (kinets $50-\mathrm{kh}$ - pochatok 70-kh rr. XX st.) [Research as one of the development measures of students' research skills on natural sciences lessons (late 50's - early 70's XX century)]. Pedagogical almanac. No. 44. pp. 272-283. https:/ /doi.org/10.37915/pa.vi44.49 [in Ukrainian].
5. Prots, M. (2015). Pedahohy-novatory Ukrainy [Teachers-innovators of Ukraine]. Lviv, 148 p. [in Ukrainian].

6. Yurchonok, Yu. V. (2009). "Avtorska shkola": do vyznachennia sutnosti poniattia ["Author's school": to determine the essence of the concept]. Humanization of the educational process. No. XLVI,pp. 293-296. [inUkrainian].

7. OECD (2019), PISA 2018 Results (Volume I): What Students Know and Can Do, PISA, OECD Publishing, Paris, 352 p. https://doi.org/10.1787/ 5f07c754-en. [in English].

Стаття надійшла до редакції 15.12.2020

УДК 373.29

DOI:

Марія Чепіль, доктор педагогічних наук, професор, завідувач кафедри загальної педагогіки та дошкільної освіти Дрогобииького державного педагогічного університету імені Івана Франка

\section{РОЗВИТОК ТЕОРЕТИЧНИХ ЗАСАД ВИХОВАННЯ ДІТЕЙ У ЗАКЛАДАХ ДОШКІЛЬНОЇ ОСВІТИ ПОЛЬЩІ}

У статті охарактеризовано зміст поняття “виховання” у педагогічній літературі Польщі. Акиентовано увагу на вихованні дітей від трьох до шести років. Мету і зміст виховання визначає базова програма дошкільної освіти. Зазначено, щзо виховна діяльність спрямована на засвоєння дитиною правил самообслуговування, спілкування і співпраџі з однолітками та дорослими. Основною метою дошкільної освіти є підготовка дитини до школи. Вагомий вплив на формування особистості дитини має оточення, місие ї перебування, ситуації, стосунки. Скоординований та інтегрований процес освітньої діяльності, певна узгодженість закладу дошкільної освіти та сім'ї вихованця може вплинути на досягнення очікуваних педагогічних результатів

Ключові слова: діти; виховання; дошкільна освіта; заклад дошкільної освіти; Польща.

Лim. 13.

Mariya Chepil, Doctor of Sciences (Pedagogy), Professor, Head of General Pedagogy and Preschool Education Department of Drohobych Ivan Franko State Pedagogical University

\section{DEVELOPMENT OF THEORETICAL PRINCIPLES OF CHILDREN'S EDUCATION IN POLISH PRESCHOOLS}

The article describes the meaning of the concepts "education" and "preschool education" in the pedagogical literature of Poland. Emphasis is placed on raising children of three to six years of age. The purpose and content of the education is determined by the basic program of preschool education. The activities of educators are aimed at teaching the rules of self-care, communication and collaboration with peers and adults. Preschool education plays an immense role in the mental, social and physical development of the child. An important condition for satisfying the children's curiosity about the world and people is their interaction with others, and their acquaintance with peers. Research shows that a child will solve problems faster in collaboration with another child (even without the help of adults). Moreover, there is no other period in human life when a child is so eager to learn and to obey the discipline and perform the duties imposed by others, than in preschool. Therefore, maintaining relations with adults and peers are a very important condition for the development of a child of preschool age.

The preschool education provides an opportunity to gain knowledge and discover the world around. It is aimed at preparing the child for learning and living in primary school after reaching the school maturity. Preparing a five-year-old child for school is a priority of preschool education. The environment, situations and relations are of great importance for the formation of the child's personality. Cooperation between the family and the preschool institution plays an important role in the upbringing of a preschool child. The coordinated and integrated process of educational activity, and a certain coordination of the preschool and the child's family can influence the achievement of the expected pedagogical results. 